\title{
Peningkatan hasil belajar matematika materi menggunakan pecahan dalam pemecahan masalah dengan pendekatan Contextual Teaching Learning (CTL)
}

\author{
Asrial*) $^{*}$ \\ SDN 10 Koto Jua Kecamatan Bayang \\ *) Correspondence e-mail: asrial@gmail.com
}

\begin{abstract}
Learning mathematics using fractions in problem-solving is boring for students. For this reason, researchers are interested in improving the process of learning mathematics, especially learning Using Fractions in Problem Solving with the Contextual Teaching Learning (CTL) approach. The CTL approach is felt to be able to overcome the existing problems. This study aims to describe the planning, implementation, and assessment of mathematics learning outcomes improvement using fractions in problemsolving with a contextual approach. The implementation of this research uses a qualitative and quantitative approach using a class action research design which includes: (1) Planning, (2) Implementation, (3) Observation and (4) Reflection. The study was conducted in 2 cycles. Research data in the form of information about the process and action data obtained from observations, test results, discussions and documentation. Research subjects consisted of Class V students totaling 20 students. The average percentage of completeness of learning outcomes in research conducted in the first cycle of meeting 1 was $60 \%$, in cycle I meeting 2 was $70 \%$, the average learning outcomes in cycle II meeting 1 was $80 \%$, in cycle II meeting 2 was $90 \%$. The conclusion obtained from this study is the CTL approach can improve learning outcomes Using Fractions in Problem Solving, namely about multiplication and division of fractions.
\end{abstract}

Keywords: matematika, contextual teaching learning (CTL)

Article History: Received on 05/12/2019; Revised on 26/11/2019; Accepted on 12/12/2019; Published Online: 20/12/2019.

\section{INTRODUCTION}

Pendidikan merupakan hal yang sangat penting karena melalui pendidikan kita dapat menghasilkan manusia yang berkualitas. Pendidikan formal utama dimulai dari Sekolah Dasar sampai Perguruan Tinggi. Sekolah Dasar mempunyai tugas dan tanggung jawab untuk meletakkan dasar-dasar pengetahuan sikap, keterampilan dan kemampuan dasar untuk mengikuti jenjang yang lebih tinggi. Oleh sebab itu pembelajaran di SD harus dilaksanakan dengan sebaik-baiknya. Untuk itu siswa harus memahami apa yang dipelajari secara langsung dalam kehidupan nyata.

Matematika sebagai salah satu ilmu pengetahuan yang diajarkan di SD, merupakan kajian yang selalu menarik untuk dikemukakan karena pada hakekatnya matematika 
adalah ilmu deduktif yang abstrak sedangkan anak usia SD relatif berada dalam pemikiran kongkrit dengan kemampuan yang bervariasi.

Berdasarkan Depdiknas (2006: 428) salah satu standar kompetensi pembelajaran Matematika di kelas V SD adalah Menggunakan Pecahan dalam Pemecahan Masalah dan kompetensi dasarnya Mengalikan dan membagi berbagai bentuk pecahan, penulis temui masih rendah karena hasil belajar siswanya pada umumnya masih di bawah kriteria ketuntasan maksimal (KKM) 75\%, dimana 15 dari 20 orang siswa yang masih rendah. Hal ini disebabkan guru dalam menyampaikan materi hanya dengan pendekatan konvensional dimana pembelajaran dengan menggunakan metode ceramah berarti pembelajaran berpusat pada guru (Teacher Center) bukan student center (berpusat pada siswa). Jadi siswa tidak aktif, komunikatif hanya terjadi pada satu arah. Alat dan media tidak digunakan dalam proses pembelajaran. Sehingga pembelajaran kurang bermakna dan tidak menyenangkan. Bahasa yang digunakan kurang dipahami oleh siswa. Begitu juga guru dalam menjelaskan materi terlalu cepat, bila ditanya siswa atau diberi kesempatan bertanya, siswa hanya diam. Apakah sudah dipahami atau tidak dimengerti sama sekali.

Jika masalah ini dibiarkan berlarut-larut akan mengakibatkan mutu pelajaran matematika terutama pada Menggunakan Pecahan dalam Pemecahan Masalah rendah. Untuk itu penulis ingin memperbaikinya dengan menggunakan pendekatan Kontekstual (contextual teaching and learning) CTL. Kontekstual merupakan salah satu pendekatan pembelajaran yang lebih bermakna yang berlangsung alamiah dalam bentuk kegiatan. Siswa, bekerja dan mengalami, bukan mentransfer pengetahuan dari guru ke siswa.

Berdasarkan kenyataan di atas, maka penulis tertarik untuk menghubungkan penerapan, pendekatan konstekstual (contextual teaching and learning) melalui suatu penelitian dengan judul: "Peningkatan Hasil Belajar Matematika Materi Menggunakan Pecahan dalam Pemecahan Masalah Dengan Pendekatan Kontekstual (CTL)".

\section{METHOD}

Penelitian ini dilaksanakan di kelas V SD Negeri 10 Koto Jua Kecamatan Bayang Sebagai subjek dalam penelitian ini adalah guru dan siswa kelas V SD Negeri 10 Koto Jua Kecamatan Bayang yang terdaftar pada semester II tahun ajaran 2017/2018, dengan jumlah siswa 20 orang. Peneliti mengambil subjek penelitian di kelas $\mathrm{V}$ karena pembelajaran Menggunakan Pecahan dalam Pemecahan Masalah merupakan permasalahan yang terdapat pada siswa kelas V SD Negeri 10 Koto Jua Kecamatan Bayang.

Pendekatan yang dipergunakan dalam penelitian ini adalah pendekatan kualitatif. Menurut Suharsimi (2008:11) "Pendekatan kualitatif digunakan karena pelaksanaan penelitian terjadi secara ilmiah, apa adanya dalam situasi normal dan tidak dimanipulasi keadaan dan kondisinya, menekankan pada deskripsi secara alami, dan menutup keterlibatab peneliti secara langsung di lapangan".

Jenis penelitian yang dilaksanakan adalah penelitian Tindakan Kelas (Classroom Action Research) yang terfokus pada upaya untuk mengubah kondisi riil sekarang ke arah yang diharapkan (Improvement Oriented). 
Penelitian ini diawali dengan adanya observasi terhadap proses pembelajaran Menggunakan Pecahan dalam Pemecahan Masalah pada siswa di kelas V SD Negeri 10 Koto Jua Kecamatan Bayang Kegiatan ini dilakukan untuk mengetahui permsalahan yang dihadapi berkaitan dengan proses pembelajaran Menggunakan Pecahan dalam Pemecahan Masalah pada siswa di kelas V SD Negeri 10 Koto Jua Kecamatan Bayang.

Data penelitian berupa observasi, hasil tes, diskusi dan dokumentasi dari setiap tindakan perbaikan peningkatan hasil belajar Menggunakan Pecahan dalam Pemecahan Masalah melalui pendekatan CTL siswa kelas IV SD yang diteliti. Data tersebut berisi tentang hal-hal yang berkaitan dengan perencanaan, pelaksanaan, dan hasil pembelajaran yang berupa informasi berikut: 1) Pelaksanaan pembelajaran yang berhubungan dengan perilaku guru dan siswa yang meliputi interaksi belajar-mengajar antara guru dan siswa, siswa dengan siswa, siswa dengan guru dalam proses pembelajaran matematika; 2) Evaluasi peningkatan hasil belajar Menggunakan Pecahan dalam Pemecahan Masalah berupa evaluasi proses maupun evaluasi hasil; 3) Hasil tes dilaksanakan sesudah pelaksanaan tindakan pembelajaran perkalian dan pembagian pecahan.

Sumber data penelitian adalah proses pembelajaran Menggunakan Pecahan dalam Pemecahan Masalah pada siswa kelas V SD Negeri 10 Koto Jua Kecamatan Bayang , yang meliputi perencanaan pembelajaran, pelaksanaan pembelajaran, kegiatan evaluasi pembelajaran prilaku guru dan siswa selama proses pembelajaran. Data diperoleh dari subjek yang diteliti, yakni guru dan siswa kelas V SD Negeri 10 Koto Jua Kecamatan Bayang

Data yang diperoleh dalam penelitian menggunakan model analisis data kualitatif. Model data kualitatif oleh Husain (2003: 84-86) yakni analisis data dimulai dengan menelaah sejak pengumpulan data sampai seluruh data terkumpul. Data tersebut direduksi berdasarkan masalah yang diteliti, diikuti penyajian data dan terakhir penyimpulan atau verifikasi.

Tahap analisis yang demikian dilakukan berulang-ulang begitu data selesai dikumpulkan pada setiap tahap pengumpulan data dalam setiap tindakan. Tahap analisis data tersebut dapat diuraikan sebagai berikut menelaah data yang terkumpul dengan melakukan transkripsi hasil pengamatan, penyeleksian dan pemilihan data.

Kemudian data tersebut direduksi melalui pengkategorian danpengklasifikasian sesuai dengan fokus masing-masing. Dengan menyeleksi mana yang relevan dan mana yang tidak relevan. Kemudian data tersebut disajikan dengan cara mengorganisasikan informasi yang telah direduksi melalui rangkuman yang disajikan secara terpadu. Barulah terakhir dengan menyimpulkan hasil penelitian.

\section{RESULTS AND DISCUSSION}

\section{Hasil Penelitian}

Pelaksanaan penelitian ini pada siswa kelas V SD Negeri 10 Koto Jua Kecamatan Bayang, tentang pembelajaran Menggunakan Pecahan dalam Pemecahan Masalah semester II tahun ajaran 2017/2018 Dalam pelaksanaan tindakan pembelajaran, peneliti bertindak sebagai guru (praktisi) sedangkan guru senior sebagai pengamat (observer). 
Pembelajaran Menggunakan Pecahan dalam Pemecahan Masalah dilaksanakan 2 siklus dengan rentang waktu 2 minggu. Sikulis I dilaksanakan 2 kali pertemuan yaitu pertemuan pertama pada tanggal 15 Januari 2018, dengan waktu 2 x 35 menit, mulai pukul 07.30 - 08.40 .Pertemuan kedua pada tanggal 17 Januari 2018 dengan waktu 2 x 35 menit, mulai pukul 07.30 - 08.40. Siklus II dilaksanakan 2 kali pertemuan yaitu pretemuan pertama pada tanggal 29 Januari 2018, dengan waktu 07.30-08.40. Pertemuan kedua pada 1 Februari 2018 dengan waktu 07.30-08.40. Adapun rincian hasil-hasil penelitian pada setiap siklus sebagai berikut:

Perencanaan. Sebelum pembelajaran Menggunakan Pecahan dalam Pemecahan Masalah melalui pendekatan CTL dilaksanakan, terlebih dahulu disusun rencana pelaksanaan pembelajaran (RPP) dan instrumen menunjang penelitian. Perencanaan pembelajaran ini disusun secara kolaboratif antara peneliti dengan guru kelas V SD Negeri 10 Koto Jua Kecamatan Bayang.

Untuk mencapai hasil pembelajaran tersebut, perencanaan pembelajaran dibagi tiga tahap pembelajaran yaitu tahap awal 10 menit, tahap inti 45 menit dan akhir 15 menit. Dalam proses pembelajaran dibagi atas 7 langkah penggunaan CTL yaitu; 1) Mengembangkan pemikiran siswa dengan cara bekerja sendiri, dan mengkonstruksi sendiri pengetahuan dan keterampilan barunya, 2) Melaksanakan sejauh mungkin kegiatan ingkuiri, 3) Mengembangkan sifat ingin tahu siswa dengan bertanya, 4) Menciptakan masyarakat belajar, 5) Hadirkan model sebagai contoh pembelajaran, 6) Melakukan refleksi di akhir pertemuan, 7) Melakukan penilaian sebenarnya dengan berbagai cara.

Pelaksanaan. Pembelajaran diawali dengan mengucapkan salam dan memperhatikan kondisi kelas untuk memulai pelajaran kemudian berdoa, mengambil absen, menyampaikan tujuan pembelajaran yaitu: menghitung perkalian dan pembagian pecahan serta menemukan dan mengunakan cara perkalian dan pembagian pecahan dengan langkah sebagai berikut :

1. Mengembangkan pemikiran siswa. Pada langkah mengembangkan pemikiran siswa yang dilakukan adalah meminta siswa mengamati lingkungan sekitar untuk menanyakan benda-benda di lingkungan sekitar dan mengelompokkan benda-benda yang jumlahnya banyak. Dalam menyebutkan nama benda yang jumlah sedikit dan benda yang jumlahnya banyak. Dari jawaban yang diberikan siswa, guru menyamakan persepsi tentang cara mudah mnghitung benda yang jumlah banyak. Kemudian siswa menghitung jumlah kursi dan meja dengan perkalian.

2. Kegiatan inkuiri. Pada langkah melaksanakan kegiatan inkuiri, guru memberikan contoh soal perkalian dan sisiwa menemukan sendiri cara perkalian bersusun panjang. Kemudian guru membimbing siswa mengerjakan soal perkalian

3. Bertanya. Pada langkah mengembangka sifat ingin tahu siswa, yaitu dengan bertanya jawab tentang perkalian pecahan dengan cara bersusun panjang yang ditemukan dan membimbing siswa mencari hasil perkalian dengan cara bersusun panjang. Untuk mengetahui apakah siswa sudah menemukan apa yang diketahui, ditanya, dan penyelesaian dari soal guru memberikan pertanyaan kepada siswa. Masih banyak siswa yang belum berani untuk mengemukakan pendapatnya. 
4. Masyarakat belajar. Pada langkah menciptakan masyarakat belajar, guru membagi siswa dalam 4 kelompok (kelompok 1 sampai 4). Siswa memecahkan permasalahan tentang perkalian dalam kehidupan sehari-hari dalam kelompok dengan bimbingan guru. Guru membagikan LKS kepada masing-masing kelompok. Kegiatan diskusi belum berjalan dengan baik karena siswa masih belum terbiasa. Kemudian masingmasing kelompok melaporkan tugas kelompoknya. Di sini masih terlihat siswa yang belum berani ke depan kelas.

5. Permodelan. Hadirkan model sebagai contoh pembelajaran, guru meminta perwakilan kelompok melaporkan tugas kelompok. Guru dapat membedakan siswa yang berani ke depan kelas dengan yang tidak. Mengoreksi tugas kelompok secara klasikal dengan menggunakan media yang dimiliki.

6. RefleksiLakukan refleksi di akhir pertemuan, guru memberikan kesempatan kepada siswa untuk mengingat kembali apa yang telah dipelajari. Guru meminta siswa menjelakan cara mencari perkalian serta mencatat di buku catatan tentang pelajaran materi perkalian dan pembagian pecahan di akhir pelaksanaam tindakan ini adalah membimbing siswa menyimpulkan pelajaran.

7. Penilaian sebenarnya. Pada langkah melakukan penilaian sebenarnya dengan berbagai cara, yaitu dengan memberikan soal latihan berupa essay sebanyak 5 buah dan memberikan penilaian terhadap tugas yang dikerjakan. Dalam tes tersebut ada beberapa siswa yang tidak dapat menyelesaikan soal mencari hasil perkalian dengan cara bersusun panjang, sehingga nilai yang diperolehnya rendah.

Rangkaian belajar melalui pendekatan CTL, diakhiri dengan perhitungan nilai masing-masing siswa dan menganalisis dan mebandingkaknya dengan KKM yang telah ditetapkan setiap mmateri atau SK/KD.

Pengamatan. Pengamatan dilakukan oleh guru kelas IV sebagai kolaborator atau teman sejawat pada waktu peneliti melaksanakan tindakan pembelajaran perkalian dan pembagian pecahan. Pengamatan dari aspek guru dan siswa selama mengikuti proses pembelajaran sebagai berikut:Penilaian RPP, dari segi pelaksanaan guru, dari segi aktivitas siswa, dan hasil belajar

Refleksi. Refleksi dilaksanakan setiap selesai pertemuan pada setiap siklusnya. Hasil pada siklus satu sebagai pedoman pelaksanaan siklus II

\section{Pembahasan}

\section{Pembahasan Siklus I}

Dari hasil penelitian siklus I pertemuan 1 diperoleh bahwa penerapan pendekatan CTL belum terlaksana dengan baik atau yang ditargetkan, hal ini dapat terlihat dari hasil observasi selama pelaksanaan pembelajaran dan dari aktivitas siswa. Di samping itu, siswa terlihat masih kurang tertarik untuk mengikui pembelajaran dan kurang memahami materi pembelajaran dengan baik. Hal ini terlihat ketika siswa diminta untuk menjawab pertanyaan guru, namun hanya beberapa siswa yang dapat menjawab pertanyaan dengan benar. Namun dari hasil tes yang diperoleh sudah terlihat siswa memahami materi dengan baik walaupun masih ada beberapa siswa yang mendapat nilai rendah. Hal ini dikarenakan kemampuan siswa yang berbeda-beda. 
Berdasarkan hasil pengamatan dan diskusi peneliti dengan guru kelas IV, penyebab belum terlaksananya pendekatan CTL pada siklus I ini adalah kurang aktifnya siswa dalam proses pembelajaran, kurangnya penenaman konsep Menggunakan Pecahan dalam Pemecahan Masalah kepada siswa. Sebaiknya penanaman konsep Menggunakan Pecahan dalam Pemecahan Masalah disertai penggunaan media yang bervariatif sehingga siswa aktif dan tertarik untuk mengikuti proses pembelajaran.

Penyebab lain dari kurang terlaksananya pendekatan CTL ini adalah guru terlalu cepat menyampainya materi sehingga banyak siswa yang kurang memahami penjelasan guru. Berdasarkan hasil penelitian dan analisis data pada siklus I pertemuan 1 diketahui bahwa persentase perencanaan mencapai $60 \%$ persentase pelaksanaan aspek guru $83 \%$ dan aspek siswa $83 \%$, dan evaluasi proses belum menunjukkan keberhasilan dengan baik serta evaluasi hasil 76\%. Dengan mengerjakan soal berbentuk essay sebanyak 5 buah. Dan persentase analisis data pada siklus I pertemuan 2 perencanaan mencapai $70 \%$, persentase pelaksanaan aspek guru $78 \%$ dan aspek siswa $78 \%$, dan evaluasi proses belum menunjukkan keberhasilan dengan baik serta evaluasi hasil 70\%. Dengan mengerjakan soal berbentuk essay sebanyak 5 buah. Berdasarkan hasil pengamatan yang diperoleh pada siklus I maka direncanakan untuk melakukan sklus II dengan tujuan agar siswa lebih aktif dan tertarik untuk belajar.

Pendekatan CTL memberikan motivasi kepada siswa. Motivasi yang diberikan oleh pendekatan CTL berupa kemauan berbuat lebih baik demi masa depan dalam rangka menentukan tujuan yang ingin dicapaidemi peningkatan hasil belajar sehingga siswa dapat aktif dan tertarik untuk mengikuti pembelajaran. Pada Siklus II diharapkan dari penerapan pendekatan CTL ini dapat terlaksana dengan baik. Untuk itu penilaian terhadap tugas siswa dengan mengerjakan pada pertemuan 1 dan 2 masing-masing 5 buah soal dalam bentuk essay. Namun hasil yang diharapkan masih banyak dari siswa kelas IV yang mendapatkan nilai di bawah standar ketuntasan. Untuk itu peneliti melaksanakan siklus II sebagai perbandingan apakah pendekatan CTL dapat dilaksanakan pada kelas V Sekolah Dasar pada pembelajaran perkalian dan pembagian pecahan.

\section{Pembahasan Siklus II}

Perencanaan yang dibuat pada siklus II telah dapat terlaksana dengan baik. Pelaksanaan pembelajaran telah sistematis dengan perencanaan sehingga pembelajaran dengan pendekatan CTL pada siklus II ini telah dapat terlaksana dengan baik.

Dalam pelaksanaan pembelajaran pendekatan CTL nampak siswa aktif dan semangat dalam belajar, terutama dalam proses menemukan sendiri rumus perkalian bilangan cacah. Siswa bisa mengotak atik sendiri soal yang diberikan guru. Kemudian dalam hal menjawab pertanyaan, siswa sudah berani mengeluarkan pendapatnya.

Di samping itu, guru banyak memberikan kesempatan kepada siswa untuk melakukan tanya jawab, hal ini dapat terlihat ketika masing-masing kelompok melaporkan hasil diskusi dan pada saat memberikan tanggapan. Siswa telah berani melaporkan hasil diskusinya ke depan kelas dan kelompok lain memberikan tanggapan dan melakukan tanya jawab. Dengan adanya keinginan siswa untuk melaporkan hasil diskusi ke depan kelas berarti telah menunjukkan adanya keterampilan proses dalam pembelajaran Menggunakan Pecahan dalam Pemecahan Masalah pada diri siswa. 
Terhadap siswa yang telah paham akan materi yang telah dipelajari maka guru memberikan umpan balik dan penguatan, sehingga siswa selalu termotivasi untuk belajar. Hal ini sesuai dengan pendapat Massofa (2009: 1) "Penguatan yang diberikan kepada siswa menyebabkan siswa termotivasi untuk belajar, dapat mengontrol dan memotivasi perilaku yang negatif, menumbuhkan rasa percaya diri, dapat memelihara iklim kelas yang kondusif, serta dapat menyebabkan siswa terdorong untuk mengulangi atau meningkatkan perilaku yang baik tersebut".

Berdasarkan uraian di atas, maka dapat disimpulkan bahwa dengan menerapkan pendekatan CTL dapat membuat siswa tertarik dan termotivasi untuk belajar. Hal ini berarti pendekatan CTL dapat digunakan oleh guru sebagai suatu pendekatan yang baik untuk diterapkan dalam proses pembelajaran sehingga dapat mencapai tujuan yang diinginkan serta dapat menciptakan suasana belajar yang menyenangkan bagi siswa. Dari analisis penelitian siklus II pertemuan 2 nilai penerapan pendekatan CTL telah mencapai 90\% (keberhasilan sangat baik) baik perencanaan, pelaksanaan, evaluasi proses dan hasil. Berdasarkan hasil yang diperoleh pada siklus II, maka pelaksanaan siklus II telah terlaksana dengan baik dan guru telah berhasil menerapkan pendekatan CTL pada pembelajaran Menggunakan Pecahan dalam Pemecahan Masalah di kelas V SD Negeri 10 Koto Jua Kecamatan Bayang

\section{CONCLUSIONS}

Berdasarkan hasil penelitian dan pembahasan maka peneliti dapat menyimpulkan sebagai berikut: 1) Perencanaan yang matang, pemilihan metode, media yang sesuai dengan materi yang diajarkan oleh guru. Perencanaan pembelajaran dengan menggunakan langkah-langkah pendekatan CTL terdiri dari 7 langkah yaitu konstruktivisme, inkuiri, bertanya, masyarakat belajar, permodelan, refleksi dan penilaian otentik. Keseluruhan langkah pembelajaran ini terlihat pada kegiatan awal, inti dan akhir; 2) Pelaksanaan pembelajaran dengan menerapkan pendekatan CTL dilaksanakan 2 siklus. Masing-masing siklus dilaksanakan 2 pertemuan. Pembelajaran dengan pendekatan CTL mempunyai 7 langkah yaitu: mengembangkan pemikiran siswa dengan cara bekerja sendiri, melaksanakan kegiatan inkuiri, mengembangkan sifat ingin tahu siswa dengan bertanya, menciptakan masyarakat belajar, menghadirkan model pembelajaran, melakukan refleksi di akhir pertemuan, melakukan penilaian sebenarnya; 3) Peningkatan hasil belajar dapat dilihat dari hasil persentase ketuntasan dan aktivitas belajar siswa melalaui pendekatan CTL mencapai $98 \%$.

\section{REFERENCES}

Aderusliana. (2007). Konsep Dasar Evaluasi Hasil Belajar (workpress. Com/ 2007/ 11/ 05/ Konsep Dasar Evaluasi Hasil Belajar/Diakses pada tanggal 2 Januari 2018)

Akhmad, Sudrajat. Pembelajaran Kontekstual.

Arikunto, Suharsimi. (2006). Penelitian Tindakan Kelas, Jakarta: Bumi Aksara 
Betzekni. (2009). Peningkatan Hasil Belajar Luas Bangun Datar Melalui Pendekatan Contekstual Teaching And Learning Pada Siswa Kelas III SDN 13 Pauh Kota Padang, Padang:. PGSD UNP.

Depdiknas. (2006). Kurikulum Tingkat Satuan Pendidikan. Jakarta: Depdiknas.. Erna, Suwangsih. (2006). Model Pembelajaran Matematika. Bandung: PRESS.

Karso. (2000). Pendidikan Matematika I. Jakarta: Universitas Terbuka.

Khafid. M. (2002). Matematika Penekanan pada Berhitung. Jakarta: Erlangga.

Mulyasa. (2007). Menjadi Guru Profesional. Bandung: PT. Remaja Rosdakarya

Sugiono. (2008). Metode Penelitian Kuantatif dan Kuaitatif. Bandung: PT. Alberta.

Wina, Sanjaya. (2008). Strategi Pembelajaran Berorientasi Standar Proses Pendidikan. Jakarta:. Kencana Prenada Media Group.

Yatim. Riyanto. (2009). Paradigma Baru Pembelajaran sebagai Referensi Bagi Pendidikan Dalam Implementasi Pembelajaran yang Efektif dan Berkualitas. Jakarta: Kencana Pranada Media Group. 